

NICOLE STAROSIELSKI

\section{the undersea network}

Duke University Press Durham and London 2015 
(C) 2015 Duke University Press

All rights reserved

Printed in the United States of America on acid-free paper $\infty$

Designed by Courtney Leigh Baker

Typeset in Gill Sans and Whitman by BW\&A Books, Inc.

Library of Congress Cataloging-in-Publication Data

Starosielski, Nicole, 1984-

The undersea network / Nicole Starosielski.

pages $\mathrm{cm}$-(Sign, storage, transmission)

Includes bibliographical references and index.

ISBN 978-0-8223-5740-7 (hardcover : alk. paper)

ISBN 978-o-8223-5755-1 (pbk. : alk. paper)

ISBN 978-o-8223-7622-4 (e-book)

1. Cables, Submarine. 2. Fiber optic cables. 3. Tele-

communications lines. 4. Telecommunication cables.

5. Communication, International. I. Title. II. Series:

Sign, storage, transmission.

TK5103.15.S737 2015

$384 \cdot 3^{\prime} 2-\mathrm{dc} 232014037968$

Cover art: Cable landing, Guam. Photo by the author.

Concept map illustrations for each chapter drawn by Cameron Rains.

Duke University Press gratefully acknowledges the support of the Humanities Initiative Grants-in-Aid, New York University, which provided funds toward the publication of this book. 
for my family 
